\title{
Multidisciplinary team care in lung cancer
}

In many centres, particularly those with adequate resources, the care of people with lung cancer includes the multidisciplinary team (MDT) as an essential component.

Over the last century or more, lung cancer has grown to become one of the most common causes of cancer death in both men and women worldwide, driven largely by the tobacco pandemic that emerged one hundred years ago. In 2018, lung cancer was the commonest cancer worldwide with over 2 million new cases and was the leading cause of cancer death in men and the second highest cause of cancer death in women (1). The epidemiology of lung cancer has become more complex this century, with better understanding of occupational and environmental risk factors (2) and differing biology of the disease in women (3).

In recent decades, innovations in diagnosis and treatment have started to erode the previously dismal survival rates. Lung cancer screening with low-dose computed tomography can reduce lung cancer mortality in high-risk groups with a significant history of tobacco smoking (4,5). Cessation of tobacco after the diagnosis of lung cancer can improve survival across all stages (6) and may infer significant cost savings for therapy (7). In 2019, the American Lung Association reported for the last 10 years an increase in overall five-year survival for lung cancer, from $17.2 \%$ to $21.7 \%$ (8), during a period that saw the introduction of screening and the advent of newer therapies for advanced disease. The introduction of immunotherapeutic agents for locally advanced non-small cell cancer (9) as well as in metastatic disease (10) may promise, in some groups, remarkable improvements in outcomes.

As treatment options have expanded, the need for high-level multidisciplinary skills has grown for all steps of the journey including accurate diagnosis and staging as well as for the delivery of cutting-edge, coordinated care. This may include interventional bronchoscopy techniques for accurate pre-operative staging (11), advances in surgical techniques (12), pathological and molecular diagnosis $(13,14)$ and the advantages of early palliative care approaches in advanced disease (15). Recent work has emphasized the burden of psychological stress, isolation and stigma experienced by people with lung cancer $(16,17)$.

Evidence for benefits from MDT care in lung cancer includes improvements in the receipt of treatment (18) as well as better longer term outcomes including survival (19-23). Other possible benefits from MDT presentation include better recording of performance status (18) and significant differences in specific treatment $(18,22)$. Research into these benefits has accompanied the inclusion of MDT care in lung cancer by health policy recommendations in multiple jurisdictions around the world including Australia, the United Kingdom, the United States and Europe (24-27). A recent Australian policy report identified the lack of access to MDT care as a key barrier to high quality diagnostics and treatment, as well as recommending better availability of specialist nurses and psychological support (28). We need research into these areas as well (29) and comprehensive lung cancer MDTs should have the support of a wide range of specialties.

The papers in this series explore important aspects of MDT care including the early introduction of palliative care, the impact on advanced disease, optimal staging in the context of the MDT, gaps in our understanding of how to best implement and test the effects of MDTs, patient outcomes associated with MDT care, lung cancer surgery in the MDT setting and optimized approaches to data systems for the MDT. Key areas for future work include the implementation of smoking cessation programs in the multidisciplinary setting, expansion of psycho-oncological support, exploration of patient-related outcomes and the impact of allied health services, including pulmonary rehabilitation in the perioperative period. I would like to thank the authors for their highly-valued contributions and for the opportunity to unite such expert dissertations.

\section{Acknowledgments}

Funding: None.

\section{Footnote}

Provenance and Peer Review: This article was commissioned by the editorial office, Translational Lung Cancer Research for the 
series "Lung Cancer Multidisciplinary Care". The article did not undergo external peer review.

Conflicts of Interest: The author has completed the ICMJE uniform disclosure form (available at http://dx.doi.org/10.21037/ tlcr-2020-lcmc-08). The series "Lung Cancer Multidisciplinary Care" was commissioned by the editorial office without any funding or sponsorship. ES served as the unpaid Guest Editor of the series and serves as an unpaid Editorial Board of Translational Lung Cancer Research from Nov 2018 to Nov 2020.

Ethical Statement: The author is accountable for all aspects of the work in ensuring that questions related to the accuracy or integrity of any part of the work are appropriately investigated and resolved.

Open Access Statement: This is an Open Access article distributed in accordance with the Creative Commons AttributionNonCommercial-NoDerivs 4.0 International License (CC BY-NC-ND 4.0), which permits the non-commercial replication and distribution of the article with the strict proviso that no changes or edits are made and the original work is properly cited (including links to both the formal publication through the relevant DOI and the license). See: https://creativecommons.org/licenses/by-ncnd/4.0/.

\section{References}

1. Cancer today [Internet]. [cited 2020 May 14]. Available online: http://gco.iarc.fr/today/home

2. Christiani DC. Occupational Exposures and Lung Cancer. Am J Respir Crit Care Med 2020. doi: 10.1164/rccm.202004-1404ED.

3. MacRosty CR, Rivera MP. Lung Cancer in Women: A Modern Epidemic. Clin Chest Med 2020;41:53-65.

4. National Lung Screening Trial Research Team, Aberle DR, Adams AM, et al. Reduced lung-cancer mortality with low-dose computed tomographic screening. N Engl J Med 2011;365:395-409.

5. de Koning HJ, van der Aalst CM, de Jong PA, et al. Reduced Lung-Cancer Mortality with Volume CT Screening in a Randomized Trial. N Engl J Med 2020;382:503-13.

6. Dobson Amato KA, Hyland A, Reed R, et al. Tobacco Cessation May Improve Lung Cancer Patient Survival. J Thorac Oncol 2015;10:1014-9.

7. Warren GW, Cartmell KB, Garrett-Mayer E, et al. Attributable Failure of First-line Cancer Treatment and Incremental Costs Associated With Smoking by Patients With Cancer. JAMA Netw Open 2019;2:e191703.

8. Key Findings I State of Lung Cancer I American Lung Association [Internet]. [cited 2019 Nov 23]. Available online: https:// www.lung.org/our-initiatives/research/monitoring-trends-in-lung-disease/state-of-lung-cancer/key-findings.html

9. Antonia SJ, Villegas A, Daniel D, et al. Durvalumab after Chemoradiotherapy in Stage III Non-Small-Cell Lung Cancer. N Engl J Med 2017;377:1919-29.

10. Steven A, Fisher SA, Robinson BW. Immunotherapy for lung cancer. Respirology 2016;21:821-33.

11. Leong TL, Loveland PM, Gorelik A, et al. Preoperative Staging by EBUS in cN0/N1 Lung Cancer: Systematic Review and Meta-Analysis. J Bronchology Interv Pulmonol 2019;26:155-65.

12. Lim, E, Batchelor, T, Dunning, et al. IN hospital clinical efficacy, safety and oncologic outcomes from violet: a UK multi-centre RCT of VATS versus open lobectomy for lung cancer [Internet]. IASLC; 2019. Available online: https://wclc2019.iaslc.org/wpcontent/uploads/2019/08/WCLC2019-Abstract-Book_web-friendly.pdf

13. Yatabe Y, Dacic S, Borczuk AC, et al. Best Practices Recommendations for Diagnostic Immunohistochemistry in Lung Cancer. J Thorac Oncol 2019;14:377-407.

14. Rodriguez-Canales J, Parra-Cuentas E, Wistuba II. Diagnosis and Molecular Classification of Lung Cancer. Cancer Treat Res 2016;170:25-46.

15. Temel JS, Greer JA, Muzikansky A, et al. Early palliative care for patients with metastatic non-small-cell lung cancer. N Engl J Med 2010;363:733-42.

16. Chambers SK, Dunn J, Occhipinti S, et al. A systematic review of the impact of stigma and nihilism on lung cancer outcomes. BMC Cancer 2012;12:184.

17. Morrison EJ, Novotny PJ, Sloan JA, et al. Emotional Problems, Quality of Life, and Symptom Burden in Patients With Lung 
Cancer. Clin Lung Cancer 2017;18:497-503.

18. Boxer MM, Vinod SK, Shafiq J, et al. Do multidisciplinary team meetings make a difference in the management of lung cancer? Cancer 2011;117:5112-20.

19. Bydder S, Nowak A, Marion K, et al. The impact of case discussion at a multidisciplinary team meeting on the treatment and survival of patients with inoperable non-small cell lung cancer. Intern Med J 2009;39:838-41.

20. Mitchell PLR, Thursfield VJ, Ball DL, et al. Lung cancer in Victoria: are we making progress? Med J Aust 2013;199:674-9.

21. Pan CC, Kung PT, Wang YH, et al. Effects of Multidisciplinary Team Care on the Survival of Patients with Different Stages of Non-Small Cell Lung Cancer: A National Cohort Study. PLoS One 2015;10:e0126547.

22. Bilfinger TV, Albano D, Perwaiz M, et al. Survival Outcomes Among Lung Cancer Patients Treated Using a Multidisciplinary Team Approach. Clin Lung Cancer 2018;19:346-51.

23. Stone E, Rankin N, Kerr S, et al. Does presentation at multidisciplinary team meetings improve lung cancer survival? Findings from a consecutive cohort study. Lung Cancer 2018;124:199-204.

24. Cancer Institute NSW. NSW Cancer Plan 2016 [Internet] 2016 [cited 2017 Jul 20]. Available online: https://www. cancerinstitute.org.au/getattachment/cancer-plan/CancerPlan2016_Final.pdf?lang=en-AU

25. National Collaborating Centre for Cancer (UK). The Diagnosis and Treatment of Lung Cancer (Update) [Internet]. Cardiff (UK): National Collaborating Centre for Cancer(UK); 2011 [cited 2017 Apr 12]. (National Institute for Health and Clinical Excellence: Guidance). Available online: http://www.ncbi.nlm.nih.gov/books/NBK99021/

26. National Comprehensive Cancer Network. NCCN Clinical Practice Guidelines in Oncology Non-Small Cell Lung Cancer [Internet] 2016. Available online: https://www.nccn.org/professionals/physician_gls/pdf/nscl_blocks.pdf

27. Postmus PE, Kerr KM, Oudkerk M, et al. Early and locally advanced non-small-cell lung cancer (NSCLC): ESMO Clinical Practice Guidelines for diagnosis, treatment and follow-up. Ann Oncol 2017;28:iv1-21.

28. Lung Foundation Australia. Making Lung Cancer a Fair Fight. A Blueprint for Reform, 2018.

29. Lehto RH. Psychosocial challenges for patients with advanced lung cancer: interventions to improve well-being. Lung Cancer (Auckl) 2017;8:79-90.

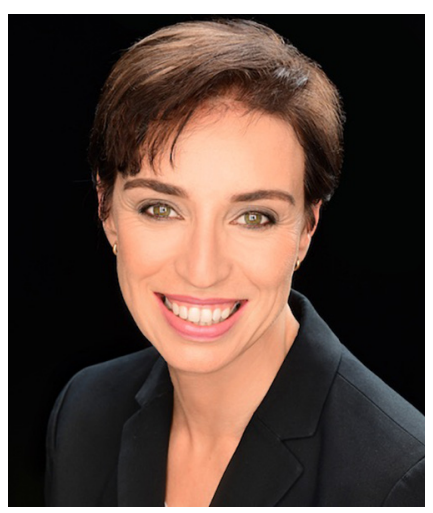

Emily Stone 


\section{Emily Stone \\ Department of Thoracic Medicine, St Vincent's Hospital Sydney, Kinghorn Cancer Centre, University of Sydney, Sydney, New South Wales, Australia. (Email: emily.stone@svba.org.au) Submitted May 14, 2020. Accepted for publication Jun 04, 2020. doi: $10.21037 /$ tlcr-2020-lcmc-08 \\ View this article at: http://dx.doi.org/10.21037/tlcr-2020-lcmc-08}

Cite this article as: Stone E. Multidisciplinary team care in lung cancer. Transl Lung Cancer Res 2020;9(4):1625-1628. doi: 10.21037/tlcr-2020-lcmc-08 